\title{
Electrocatalyst design for direct borohydride oxidation guided by first principles
}

\author{
Gholamreza Rostamikia, ${ }^{\mathrm{a}}$ Romesh J. Patel, ${ }^{\mathrm{b}}$ Irene Merino-Jimenez, ${ }^{\mathrm{c}}$ Michael Hickner, \\ and Michael J. Janik ${ }^{\mathrm{a}^{*}}$ \\ $a$ Department of Chemical Engineering, Pennsylvania State University, University Park, \\ PA 16802 \\ $b$ Department of Materials Science and Engineering, Pennsylvania State University, \\ University Park, PA 16802 \\ $c$ Bristol Robotics Laboratory, Universities of Bristol and of the West of England, Bristol \\ Business Park, Coldharbour Lane, BS16 1QY, UK
}

\begin{abstract}
Density functional theory (DFT) calculations are used to propose a Au-Cu binary metal catalyst for the electrochemical borohydride oxidation reaction (BOR), which is evaluated experimentally and observed to show enhanced oxidation activity relative to a pure Au electrode. Our previous work has applied DFT methods to determine the BOR mechanism and elucidate the key reaction steps that dictate catalyst activity and selectivity to complete oxidation. A balanced initial adsorption strength of the borohydride anion is essential for an active and selective catalyst. Adsorption must be strong enough to provide a reasonable coverage of surface species and promote $\mathrm{B}-\mathrm{H}$ bond dissociation but not so strong as to promote easy dissociation and provide a high coverage of surface $\mathrm{H}$ atoms that result in $\mathrm{H}_{2}$ evolution. Borohydride adsorption energetics were evaluated for a series of close-packed pure metal surfaces. Copper catalysts appear encouraging, but are not electrochemically stable under reaction conditions. Gold-copper alloys are predicted to show increased activity compared to a pure gold electrode, while maintaining the selectivity to direct oxidation and increasing
\end{abstract}


the stability compared to pure $\mathrm{Cu}$. DFT results suggest an approximately $0.2 \mathrm{~V}$ decrease in the overpotential for borohydride oxidation on $\mathrm{a} \mathrm{Au}_{2} \mathrm{Cu}_{1}(111)$ electrode compared to $\mathrm{a}$ Au(111) electrode. This DFT predicted reduction in overpotential is realized experimentally. Electrodeposition was used to prepare $\mathrm{AuCu}$ electrodes and their borohydride oxidation electrokinetics were examined by linear sweep voltammetry. An $88.5 \%$ gold and $11.5 \%$ copper sample demonstrated an overpotential reduction of $0.17 \mathrm{~V}$ compared to a pure Au electrode. The binding energy and adsorption free energy of $\mathrm{BH}_{4}{ }^{-}$ over other surface alloys is also examined to further identify promising BOR electrodes.

\section{Introduction}

Direct borohydride fuel cells (DBFC's) utilize a high energy density, aqueous borohydride solution to directly convert chemical energy to electrical energy. There are a number of advantages and disadvantages regarding use of these fuel cells as an alternative energy conversion device. The aqueous fuel used in DBFC's does not have the storage and handling concerns associated with hydrogen fuel cells and the final product is an environmentally benign product that may be recycled. In addition to the energy intensity of borohydride synthesis, the main challenge in developing DBFC's is the low efficiency of electrocatalysts used for the borohydride oxidation reaction (BOR). Previously tested materials, mainly noble metals, either suffer from low activity or low selectivity for the oxidation reaction, which limits the fuel cell efficiency to approximately $30 \%$.

Multiple materials have been tested experimentally as anode electrocatalysts for DBFC's. Gold ${ }^{1-5}$ and silver ${ }^{3,6}$ are more selective catalysts, which could produce up to 8 
electrons per borohydride molecule, however, the low activity of these catalysts limit the fuel cell efficiency and high overpotentials are required to draw sizable currents from these catalysts. Platinum, ${ }^{1,-8}$ nickel, $^{7-9}$ and palladium ${ }^{7}$ are more active for borohydride oxidation reactions, however an extreme activity of these catalysts for breaking B-H bonds leads to large amounts of hydrogen gas production and less than $8 \mathrm{e}^{-}$collected per borohydride molecule converted. This lack of selectivity also limits the overall efficiency of the fuel cell.

We have previously applied density functional theory (DFT) methods to evaluate the borohydride oxidation mechanism over the $\operatorname{Au}(111)^{10-11}$ and $\operatorname{Pt}(111)$ surfaces, ${ }^{12}$ as well as Pd-Ir alloys..$^{13}$ Our mechanistic studies ${ }^{10-11}$ of the BOR over the Au(111) surface concluded that the unfavorable borohydride adsorption and low activity for breaking B-H bonds causes low activity and large overpotentials. Alternatively, very exothermic, dissociative adsorption of $\mathrm{BH}_{4}{ }^{-}$ions over the platinum surface produces a large surface coverage of hydrogen. Recombination of the surface hydrogen as hydrogen molecules, competes with the surface hydrogen oxidation which causes the unselective production of hydrogen gas over this surface.

There are a few experimental attempts to use alloy catalysts for direct borohydride anodes. In most cases a combination of more selective catalysts like gold and more active catalysts like platinum or palladium is used. ${ }^{13-17}$ Non-noble metals such as Ni have also been considered for bimetallic alloys with Au. Ni would reduce the cost of the catalyst and keep or even improve the catalytic activity towards the borohydride oxidation. ${ }^{18} \mathrm{~A}$ Pt-Dy alloy electrode was also tested for the BOR reaction. ${ }^{19}$ Pt-Dy alloys show comparable current density to pure platinum at room temperature, however, they have a 
higher coulombic efficiency than platinum at elevated temperatures. Chatenet et al. reviewed and compared the activity (power density and current density) of different alloys (AuPt, PtRu, NiPt, AgNi, AuNi, NiPd) to pure gold and platinum electrodes. ${ }^{20}$ All these alloys are more active than gold electrodes, however, they also produce higher amount of hydrogen. Carbon supported palladium and copper nanoparticles were also considered for BOR and show better performance than pure palladium nanoparticles. ${ }^{21}$ DFT studies were also performed on Pd-Ir alloys for BOR, ${ }^{13}$ suggesting that the presence of Ir favored borohydride oxidation rather than the hydrogen evolution and increased the number of electrons released from the BOR when the concentration of Ir was increased.

Gold nanoparticles combined with amorphous Co-B (Au@Co-B) have been also considered for borohydride oxidation and the activity has been reported to be higher than pure gold electrodes. ${ }^{22}$ These studies have concluded that alloy electrodes may increase the power density and improve the performance of the cell, increasing the current density and decreasing the overpotential, though the majority of these are not as selective to direct oxidation as pure Au electrodes.

$\mathrm{Au}$ alloyed with $3 \mathrm{~d}$ metals have been shown to promote borohydride oxidation and retain selectivity to direct oxidation. He et al. carried out cyclic voltammetry, chronopotentiometry and chronoamperometry with different alloys composed by Au and 3d transition metals $(\mathrm{M}=\mathrm{Fe}, \mathrm{Co}, \mathrm{Ni}, \mathrm{Cu}$ and $\mathrm{Zn}) .{ }^{23}$ Besides being a less expensive catalyst for borohydride oxidation, Au-M/C alloys have a higher specific activity for borohydride oxidation than pure Au, leading to a higher open circuit potential in the DBFC and more rapid borohydride oxidation. The authors assured that Au-Zn, Au-Fe and 
$\mathrm{Au}-\mathrm{Cu}$ showed no activity towards borohydride hydrolysis, minimizing one of the main problems of the DBFC.

Density functional theory (DFT) calculations can be used to predict the relative performance of various metal alloys for the BOR. As we have identified the adsorption free energy of $\mathrm{BH}_{4}{ }^{-}$ions to the electrode surface as a key indicator of electrocatalyst activity and selectivity, its evaluation with DFT can be used to predict catalyst performance. Weak molecular bonding of $\mathrm{BH}_{4} *$ (where “*” denotes a surface species) will lead to a more selective catalyst, however, the activity of such catalysts for breaking B-H bonds will limit the activity. Strong dissociative adsorption indicates a more active catalyst, however, facile B-H dissociation will lead to a non-selective catalyst producing $\mathrm{H}_{2}$ gas as well as oxidation products. Moderate molecular adsorption of $\mathrm{BH}_{4}{ }^{-}$ions to the catalyst surface will produce the best efficiency for the BOR, balancing the activity of the catalyst while maintaining selectivity to complete oxidation.

In addition to our initial study of $\mathrm{Au}-\mathrm{Cu}$ alloys for BOR, the Kasai group has applied DFT to examine Au-based bimetallic electrocatalysts. ${ }^{24-25}$ Arevalo et al. ${ }^{25}$ used first principles calculations based on spin-polarized DFT to study the adsorption of borohydride ions on $\mathrm{Au}$ and $\mathrm{Au}_{3} \mathrm{M}(111)(\mathrm{M}=\mathrm{Cr}, \mathrm{Mn}, \mathrm{Fe}, \mathrm{Co}$ and $\mathrm{Ni})$. They obtained more favorable adsorption configurations and larger adsorption stability on the alloys than on pure Au. For all the alloys considered, the adsorption energy increased between 0.33 and $0.58 \mathrm{eV}$ compared to that on pure $\mathrm{Au}$. In the case of pure $\mathrm{Au}$, when the sp state of borohydride hybridizes with the $\mathrm{d}$ band, both bonding and antibonding states are fully occupied. The occupied states near the Fermi level contribute to a repulsive interaction due to antibonding characteristics. In the case of the alloys, the derived sp-d state is 
upshifted and becomes unoccupied unlike on pure Au. That explains the increase in the adsorption energy of borohydride on $\mathrm{Au}_{3} \mathrm{M}$ surfaces compared to pure $\mathrm{Au}$.

Herein, we apply DFT to examine a series of alloy surfaces, and present a more complete elementary borohydride oxidation path for a $\mathrm{Au}-\mathrm{Cu}$ alloy that shows strong promise for increased activity while maintaining selectivity against hydrolysis. Similar to our previous mechanistic studies over the $\operatorname{Au}(111)$ and $\operatorname{Pt}(111)$ surfaces, ${ }^{10,12}$ we use a vacuum-slab DFT model to evaluate the initial electrochemical adsorption of $\mathrm{BH}_{4}{ }^{-}$ions to a series of late transition metal surfaces. Metal alloys with potentially improved BOR performance are chosen based on a rationale developed from the pure metal behavior. The selected alloys are investigated for their initial $\mathrm{BH}_{4}{ }^{-}$adsorption strength, and the complete oxidation energetics are evaluated for the especially promising $\mathrm{Au}-\mathrm{Cu}$ catalyst. Experimental studies (electrodeposition, characterization, and voltammetry) realize the predicted enhanced activity of the $\mathrm{Au}-\mathrm{Cu}$ catalyst.

\section{Research methods}

\subsection{Computational methods}

All calculations were performed using the ab initio total-energy and moleculardynamics Vienna ab initio simulation program (VASP) developed at the Institute for Material Physics at the University of Vienna. ${ }^{26-28}$ Interactions of ions and electrons were described by using projected augmented wave method. ${ }^{29}$ Exchange and correlation energies were calculated using the Perdew-Wang form of generalized gradient approximation. $^{30}$ In all calculations, plane-wave basis sets were used with a cut off energy of $400 \mathrm{eV}$. A $3 \times 3 \times 1$ Monkhorst-Pack grid ${ }^{31}$ was used for sampling the Brillouin 
zone during optimization of structures, followed by a $4 \times 4 \times 1$ single point calculation to give the total energy. A $5 \times 5 \times 1$ Monkhorst-Pack $\operatorname{grid}^{31}$ was used for sampling the Brillouin zone to search for the saddle points using the climbing image nudged elastic band method. To determine the zero point vibrational (ZPVE) corrections to the total energy of adsorbates, the harmonic vibrational modes were calculated.

Pure metal surfaces and the $\mathrm{Au}_{2} \mathrm{Cu}_{1}$ bimetallic were modeled using a 4 layer slab and a $3 \times 3$ surface cell. An experimental value of $3.94 \AA$ was used as the lattice parameter of the $\mathrm{Au}_{2} \mathrm{Cu}_{1}$ fcc bimetallic structure. ${ }^{32}$ Two bottom layers were constrained and the two top layers of the metal slabs were allowed to relax. $13 \AA$ of vacuum was inserted between the periodic slabs. Adsorption of $\mathrm{BH}_{4}$ species and borohydride oxidation intermediates were examined over the high symmetry atop, bridge, fcc and hcp sites. The energy of the adsorbed species were corrected for spurious slab-to-slab dipole interactions along the surface normal direction (VASP keywords LDIPOL=TRUE, IDIPOL=3).

Adsorption energies and the elementary surface reactions energetics were calculated using the lowest energy adsorbed states. Calculation of the adsorption energies and the elementary surface reaction energetics has been detailed in our previous publications. $^{10,12}$

\subsection{Experimental methods}

Electrodeposition experiments and linear sweep voltammetry (LSV) experiments were carried out using a computer controlled potentiostat (PARSTAT 2273, Princeton Applied Research). An aqueous solution of $1 \mathrm{mM} \mathrm{HAuCl}_{4}, 2-5 \mathrm{mM} \mathrm{CuSO}_{4}$ and $0.05 \mathrm{M}$ $\mathrm{H}_{2} \mathrm{SO}_{4}$ was used for deposition of a $\mathrm{Au}-\mathrm{Cu}$ alloy over a $5 \mathrm{~mm}$ platinum disk electrode at 
constant potential $(-0.045 \mathrm{~V} \mathrm{Ag} / \mathrm{AgCl})$ for 1600 seconds. Prior to the deposition of the $\mathrm{Au}-\mathrm{Cu}$ alloy, the platinum electrode was polished to a mirror finish using $1 \mu \mathrm{m}$ and 0.05 $\mu \mathrm{m}$ alumina paste. The Pt electrode was chosen over a BOR-inert glassy carbon electrode because it offered more predictable electrodeposition kinetics and better adhesion of the deposited Au-Cu layer. Scanning electron microscopy (SEM, supplementary information) confirmed that the deposited thick layer did not leave any Pt exposed, and voltammetry studies showed no indication of borohydride oxidation or hydrogen evolution around -0.8 V(NHE) expected for a Pt electrode. Deposition and borohydride oxidation voltammetry experiments were performed in a standard three-electrode cell. $\mathrm{An} \mathrm{Ag} / \mathrm{AgCl}(4 \mathrm{M} \mathrm{KCl})$ reference electrode was used in all experiments, and all reported potentials are shifted to reference a normal hydrogen electrode. All potentials given in the text are relative to a normal hydrogen electrode unless otherwise noted. A platinum wire was used as the counter electrode in deposition experiments. Alternatively, for linear sweep voltammetry (LSV) tests a graphite rod was used as a counter electrode. For LSV experiments, $0.03 \mathrm{M}$ $\mathrm{NaBH}_{4}$ and $2 \mathrm{M} \mathrm{NaOH}$ were used.

2-dimentional wide angle x-ray diffraction (2D-WAXD) was carried out using a Rigaku RAPID II x-ray generator diffractometer (Tokyo, Japan) with Ni-filtered $\mathrm{Cu} \mathrm{K \alpha}$ radiation $(\lambda=1.54059 \AA)$ and a tube voltage and current of $50 \mathrm{KV}$ and $40 \mathrm{~mA}$. The incidence angle was rocked between $30^{\circ}$ and $50^{\circ}$ at a frequency of $1 \mathrm{~s}^{-1}$ for 1 hour and the resulting 2D WAXD patterns were integrated. 


\section{Results and discussion}

A more effective electrocatalyst is designed for the borohydride oxidation guided by first-principles DFT calculations, and the recommended Au-Cu binary metal catalyst is tested experimentally to confirm the improved activity. The initial adsorption strength of the $\mathrm{BH}_{4}{ }^{-}$species is examined as a design parameter in section 3.1. As the $\mathrm{Au}_{2} \mathrm{Cu}_{1}(111)$ surface is encouraging based on this initial analysis, the complete oxidation mechanism is examined over this surface in section 3.2. The optimal binding configuration and energy of the surface reaction intermediates are reported in section 3.2.1. Elementary surface reaction energetics are presented and discussed in section 3.2.2. Experimental characterization and voltammetry realizing the predicted improvement in electrocatalytic activity for the Au-Cu catalyst are presented in section 3.3. In section 3.4, DFT methods are used to generate other potentially active and selective bimetallic surfaces.

\subsection{Adsorption of $\mathrm{BH}_{4}^{-}$ions over close-packed, late transition metal surfaces}

The adsorption of the $\mathrm{BH}_{4}{ }^{-}$anion is taken to occur with electron transfer through the reaction:

$$
\mathrm{BH}_{4}^{-}(\mathrm{aq})+\mathrm{H}_{2} \mathrm{O}^{*} \rightarrow \mathrm{BH}_{4}^{*}+\mathrm{H}_{2} \mathrm{O}_{(\mathrm{aq})}+\mathrm{e}^{-}
$$

Adsorption of the borohydride ion is taken to displace a surface water molecule, which is returned to the aqueous phase upon desorption. As the adsorption reaction releases an electron, the adsorption free energy is dependent on the electrode potential. We calculate the adsorption free energy as a function of electrode potential as the difference in free energy between reactants and products in equation 1:

$$
\Delta G_{a d s}(U)=G_{B H_{4}{ }^{*}}+G_{\mathrm{H}_{2} \mathrm{O}_{a q}}-e U-G_{\mathrm{H}_{2} \mathrm{O}^{*}}-G_{B H_{4, a q}^{-}}
$$


where a "*" denotes a surface species, $U$ denotes the electrode potential on an absolute scale, and $e^{-}$is the absolute value of an elementary charge. We have previously detailed the methods used to approximate the solution phase chemical potential of the $\mathrm{BH}_{4}{ }^{-}$ion and an $\mathrm{H}_{2} \mathrm{O}$ molecule and to shift the absolute potential to the NHE scale. ${ }^{10,12}$

Table 1 presents the adsorption free energy at $-0.5 \mathrm{~V}$ and adsorbed state (molecular or dissociative) for $\mathrm{BH}_{4}{ }^{-}$adsorption over the 111 (fcc) and 0001(hcp) surfaces of late transition metals. The choice of potential at which to compare adsorption energies among metals is arbitrary, as they scale equivalently with potential. We chose $-0.5 \mathrm{~V}$ for comparison because at this potential, adsorption to $\mathrm{Au}$ is clearly too endergonic whereas adsorption to Pt is too exergonic. A surface offering an adsorption free energy near zero at this potential would offer a significant reduction in overpotential compared to $\mathrm{Au}(111)$ while potentially remaining selective against hydrolysis.

Similar to adsorption to the $\mathrm{Pt}(111)$ surface,$^{33}$ adsorption of the $\mathrm{BH}_{4}{ }^{-}$ion to Group VI-VIII metals is dissociative, resulting in adsorbed $\mathrm{BH}^{*}$ and $3 \mathrm{H}^{*}$ species. Attempts to locate a minimum energy configuration with $\mathrm{BH}_{4} *$ in a molecular state, including constrained optimizations varying the height of the B atom above the surface and including explicit water molecules to stabilize the $\mathrm{BH}_{4}{ }^{*}$ molecule, were unsuccessful. Upon exposure of these metal surfaces to the borohydride solution, the surface will likely saturate in $\mathrm{BH}^{*}$ species, and hydrogen evolution will compete with oxidation once the $\mathrm{BH}^{*}$ species are oxidized from the surface. This is in agreement with experimental borohydride oxidation tests which indicated lower selectivity and higher hydrolysis rates for platinum, ${ }^{1,7}$ palladium, ${ }^{7}$ and nickel ${ }^{7}$. 
The borohydride ion adsorbs in a molecular state on the group IB metals (Au(111), $\mathrm{Ag}(111)$ and $\mathrm{Cu}(111))$. At $-0.5 \mathrm{~V}$, adsorption over the $\mathrm{Au}(111)$ and $\mathrm{Ag}(111)$ surfaces is endergonic, however, the adsorption over $\mathrm{Cu}(111)$ is exergonic. This suggests the $\mathrm{Cu}$ electrodes might offer a better balance of greater activity than $\mathrm{Au}$ and $\mathrm{Ag}$ while maintaining higher selectivity against hydrolysis than $\mathrm{Ni}, \mathrm{Pd}$, and Pt.

A pure $\mathrm{Cu}$ electrode has been tested experimentally. ${ }^{7,34}$. Though it shows activity for borohydride oxidation, the $\mathrm{Cu}$ electrode oxidizes at potentials near that at which borohydride is oxidized. ${ }^{34-35}$ Therefore, pure $\mathrm{Cu}$ materials are not stable for use as anode electrocatalysts in borohydride fuel cells. Collectively, these results suggest that no pure metal electrocatalyst will simultaneously offer the activity, selectivity, and stability needed for use as a BOR electrocatalyst. $\mathrm{Au}-\mathrm{Cu}$ binary metals are known to be more stable than pure $\mathrm{Cu}$ versus oxidation, ${ }^{36-38}$ and we further consider their borohydride oxidation activity in the following section.

Table 1. Adsorption free energy (eV) of $\mathrm{BH}_{4}{ }^{-}$ions to (111) or (0001) late transition metal surfaces at $-0.5 \mathrm{~V}$. " $\mathrm{D}$ " indicates dissociative adsorption which will generate " $\mathrm{BH}+3 \mathrm{H}$ " on the surface; "M" indicates molecular adsorption.

\begin{tabular}{|c|c|c|c|}
\hline & $\mathbf{C o}$ & $\mathbf{N i}$ & $\mathbf{C u}$ \\
& $-1.25 \mathrm{D}$ & $-1.97 \mathrm{D}$ & $-0.44 \mathrm{M}$ \\
\hline $\mathbf{R u}$ & $\mathbf{R h}$ & $\mathbf{P d}$ & $\mathbf{A g}$ \\
$-1.60 \mathrm{D}$ & $-1.48 \mathrm{D}$ & $-2.16 \mathrm{D}$ & $0.05 \mathrm{M}$ \\
\hline $\mathbf{O s}$ & $\mathbf{I r}$ & $\mathbf{P t}$ & $\mathbf{A u}$ \\
$-1.85 \mathrm{D}$ & $-2.01 \mathrm{D}$ & $-1.85 \mathrm{D}$ & $0.54 \mathrm{M}$ \\
\hline
\end{tabular}

Figure 1 presents the adsorption configuration of $\mathrm{BH}_{4}{ }^{*}$ over the $\mathrm{Au}_{2} \mathrm{Cu}(111)$ surface. The $\mathrm{Au}_{2} \mathrm{Cu}$ stoichiometry was chosen to preserve the oxidative stability with 
majority $\mathrm{Au}$, offer the potential for improved activity with a $\mathrm{Cu}$ atom included in all hollow sites, and provide a convenient ratio for our use of $3 \times 3$ unit cells. The adsorption free energy of $\mathrm{BH}_{4}{ }^{-}$is $0.32 \mathrm{eV}$ at $-0.5 \mathrm{~V}$. This adsorption energy is $0.22 \mathrm{eV}$ less endergonic than the adsorption on the pure gold surface, or stated otherwise, the free energy of adsorption will become favorable (negative) $0.22 \mathrm{~V}$ lower over the $\mathrm{Au}_{2} \mathrm{Cu}(111)$ surface than over the $\mathrm{Au}(111)$ surface. If the limiting surface reaction energies and activation barriers are similarly shifted, a $0.22 \mathrm{~V}$ shift in the overpotential of the BOR would be expected. Considering the total $1.64 \mathrm{~V}$ theoretical cell potential of the DBFC, this $0.22 \mathrm{~V}$ potential shift could possibly lead to a $13 \%$ improvement in the overall fuel cell efficiency relative to Au anodes. With the initial adsorption free energy encouraging, we examined the surface reaction energetics of the complete borohydride oxidation over the $\mathrm{Au}_{2} \mathrm{Cu}(111)$ catalyst surface.
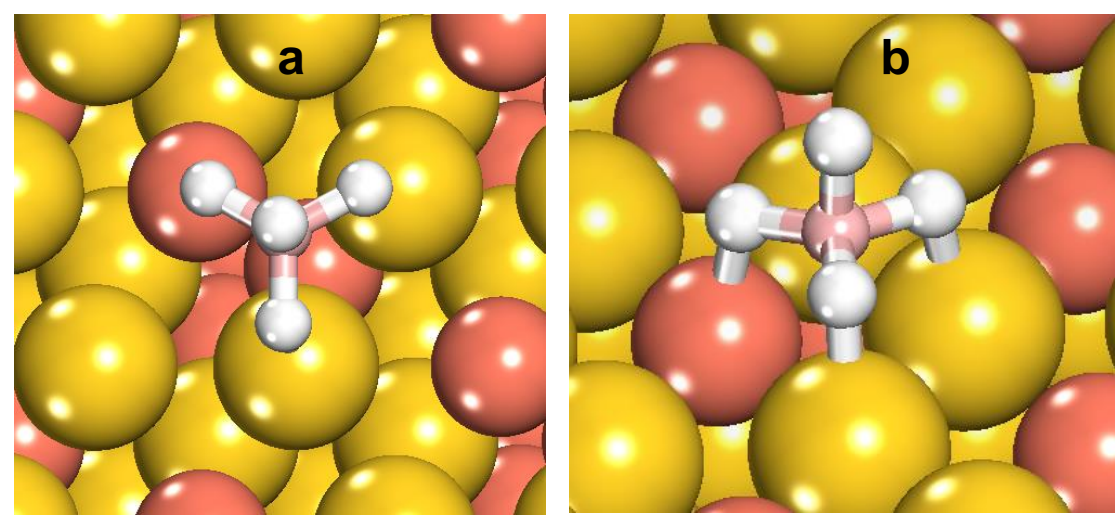

Figure 1. Adsorption configuration of $\mathrm{BH}_{4}{ }^{*}$ over the $\mathrm{Au}_{2} \mathrm{Cu}(111)$ surface a) top view b) side view

3.2. Complete borohydride oxidation mechanism over the $A u_{2} C u(111)$ intermetallic surface

3.2.1 Preferred binding site of all intermediates over the $\mathrm{A} u_{2} \mathrm{Cu}(111)$ surface 
We consider optimal binding configurations and binding energies (BE) of all possible intermediates ${ }^{10}$ of $\mathrm{BOR}$ over the $\mathrm{Au}_{2} \mathrm{Cu}(111)$ surface. Adsorption was considered over the high symmetry atop, bridge, fcc and hcp sites. Binding energy is calculated as the energy difference of the bound state and the total energy of the surface and gas phase species, with ZPVE and vibrational entropy corrections at $298 \mathrm{~K}$ included. Though the binding energy is relative to gas phase species, it is useful in identifying strongly or weakly bound species. Table 2 presents the binding energies at the optimal adsorption site and configuration over the $\mathrm{Au}_{2} \mathrm{Cu}(111)$ surface. The optimal binding configurations of intermediates are presented in Figure 2.

3.2.1.1. $\mathrm{BH}_{x}$ species. $\mathrm{BH}_{4}{ }^{*}$ species adsorb over the hcp (above a second layer $\mathrm{Cu}$ atom) hollow site with three $\mathrm{H}$ atoms pointing toward the surface making three $\mathrm{B}-\mathrm{H}-\mathrm{M}$ three centered, two electron hybrid bonds $(\mathrm{BE}=-2.08 \mathrm{eV})$. Similar to adsorption over the $\mathrm{Au}(111)$ surface, the preference for an hcp hollow site over a fcc site is minimal (-0.06 $\mathrm{eV})$. The $\mathrm{BH}_{4} \mathrm{BE}$ to the $\mathrm{Au}_{2} \mathrm{Cu}(111)$ surface is $0.35 \mathrm{eV}$ stronger than over the $\mathrm{Au}(111)$ surface. This leads to the $0.22 \mathrm{eV}$ difference in adsorption free energy calculated with Equation 2, with the increased strength in water binding to the $\mathrm{Au}-\mathrm{Cu}$ intermetallic explaining the $0.13 \mathrm{eV}$ difference. 
Table 2. Binding energies ( $\mathrm{BE}$ in $\mathrm{eV}$ ) of $\mathrm{BOR}$ intermediates over the $\mathrm{Au}_{2} \mathrm{Cu}(111)$ surface. Binding energies over the $\mathrm{Au}(111)$ surface are presented for comparison. ${ }^{10}$

\begin{tabular}{|c|c|c|}
\hline Species & $\mathrm{Au}_{2} \mathrm{Cu}(111) \mathrm{BE}$ & Au(111) BE \\
\hline $\mathrm{BH}_{4}$ & -2.08 & -1.73 \\
\hline $\mathrm{BH}_{3}$ & -0.88 & -0.55 \\
\hline $\mathrm{BH}_{2}$ & -3.13 & -2.64 \\
\hline $\mathrm{BH}$ & -4.23 & -4.40 \\
\hline $\mathrm{B}$ & -4.25 & -4.43 \\
\hline $\mathrm{BH}_{3} \mathrm{OH}$ & -1.28 & -1.08 \\
\hline $\mathrm{BH}_{2} \mathrm{OH}$ & -0.07 & -0.06 \\
\hline $\mathrm{BH}_{3} \mathrm{O}$ & -1.06 & -0.84 \\
\hline $\mathrm{BH}_{2} \mathrm{O}$ & -1.31 & -0.93 \\
\hline $\mathrm{BHOH}$ & -2.36 & -2.34 \\
\hline $\mathrm{BHO}$ & -0.61 & -0.44 \\
\hline $\mathrm{BOH}$ & -2.68 & -2.76 \\
\hline $\mathrm{BO}$ & -2.98 & -2.85 \\
\hline $\mathrm{BH}(\mathrm{OH})_{2}$ & -0.04 & -0.05 \\
\hline $\mathrm{B}(\mathrm{OH})_{2}$ & -2.21 & -2.20 \\
\hline $\mathrm{BHOOH}$ & -1.72 & -1.30 \\
\hline $\mathrm{BOOH}$ & -0.24 & -0.23 \\
\hline $\mathrm{BO}_{2}$ & -2.36 & -1.95 \\
\hline $\mathrm{B}(\mathrm{OH})_{3}$ & -0.05 & -0.30 \\
\hline $\mathrm{H}$ & -2.25 & -2.12 \\
\hline $\mathrm{OH}$ & -2.22 & -1.79 \\
\hline $\mathrm{H}_{2} \mathrm{O}$ & -0.25 & -0.11 \\
\hline
\end{tabular}




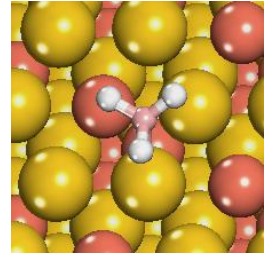

$\mathrm{BH}_{3}$ *

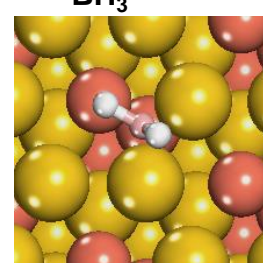

$\mathrm{BH}_{2}{ }^{*}$

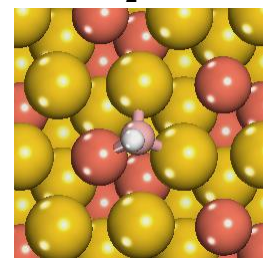

$\mathrm{BH}^{*}$

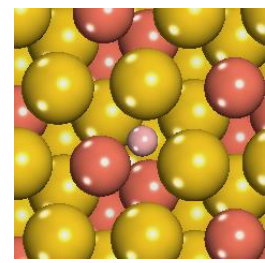

B $^{*}$

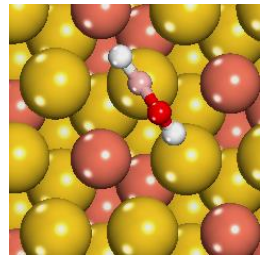

$\mathrm{BHOH}^{*}$

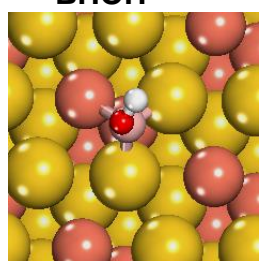

$\mathrm{BOH}^{*}$

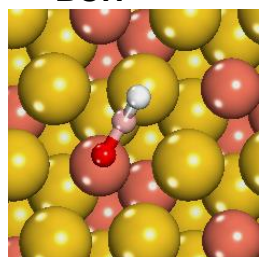

BHO*

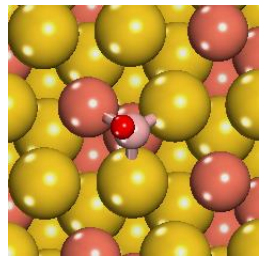

BO*

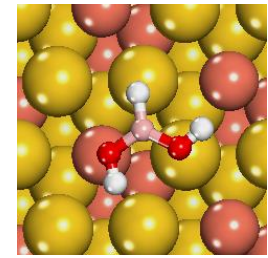

$\mathrm{BH}(\mathrm{OH})_{2}{ }^{*}$

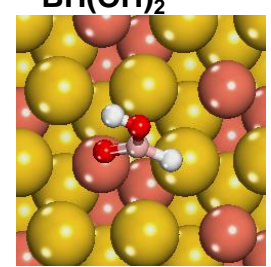

BHOOH $^{*}$

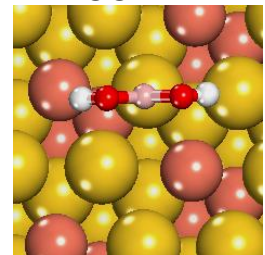

$\mathrm{B}(\mathrm{OH})_{2}$ *

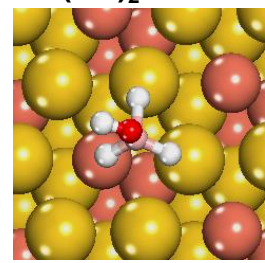

$\mathrm{BH}_{3} \mathrm{OH}^{\star}$

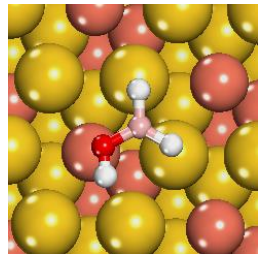

$\mathrm{BH}_{2} \mathrm{OH}^{\star}$

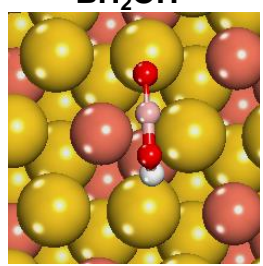

$\mathrm{BOOH}^{\star}$

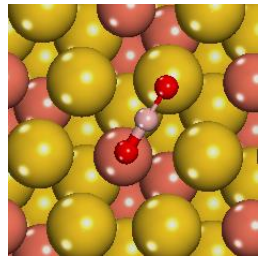

$\mathrm{BO}_{2}{ }^{*}$

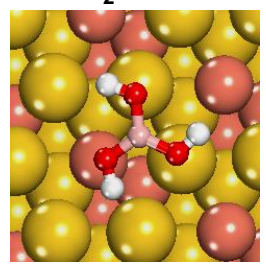

$\mathrm{B}(\mathrm{OH})_{3}{ }^{*}$

Figure 2. Optimal binding configuration of borohydride oxidation intermediates over the $\mathrm{Au}_{2} \mathrm{Cu}(111)$ surface, $\mathrm{Au}=$ gold, $\mathrm{Cu}=$ mauve; $\mathrm{H}=$ white, $\mathrm{B}=$ pink, $\mathrm{O}=$ red.

$\mathrm{BH}_{3}$ is a saturated species that binds weaker than $\mathrm{BH}_{4}$ to the surface $(\mathrm{BE}=-0.88 \mathrm{eV})$, however, the binding is $0.33 \mathrm{eV}$ stronger to the intermetallic than to the $\mathrm{Au}(111)$ surface. Stronger binding of $\mathrm{BH}_{3}$ may help limit possible desorption of this partial oxidation product. $\mathrm{BH}_{2}$ binds to the surface with the $\mathrm{B}$ atom interacting with the hollow site and one of the $\mathrm{H}$ atoms over the surface copper atom $(\mathrm{BE}=-3.13)$ and the other $\mathrm{H}$ atom is oriented away from the surface. The adsorption energy at the optimal binding configuration is about $0.49 \mathrm{eV}$ more exothermic than to the $\mathrm{Au}(111)$ surface. $\mathrm{BH}^{*}$ binds 
to the fcc hollow site with the $\mathrm{H}$ atom pointing out of the surface. Binding of $\mathrm{B}$ atoms is slightly favored over the fcc hollow site $(\mathrm{BE}=-4.25 \mathrm{eV})$ compared to the hcp site.

3.2.1.2. $\mathrm{BH}_{x} \mathrm{O}$ species. $\mathrm{BH}_{\mathrm{x}} \mathrm{O}$ species bind stronger to the intermetallic surface than the pure-Au surface. The $\mathrm{BH}_{3} \mathrm{OH}^{*}$ species adsorbs over the fcc site with two $\mathrm{H}$ atoms on top of $\mathrm{Au}$ and one $\mathrm{H}$ atom on top of $\mathrm{Cu}$ atoms $(\mathrm{BE}=-1.28 \mathrm{eV})$. The $\mathrm{OH}$ group points out of the surface. $\mathrm{BH}_{2} \mathrm{OH}^{*}$ is a stable gas phase species and, similar to the adsorption over the $\mathrm{Au}(111)$ surface, does not have a strong interaction with the surface. $\mathrm{BH}_{2} \mathrm{O}^{*}$ binds to the surface with the $\mathrm{O}$ atom over the $\mathrm{Cu}$ atop site and one of the $\mathrm{H}$ atoms over the $\mathrm{Au}$ atop site $(\mathrm{BE}=-1.31 \mathrm{eV}) . \mathrm{BOH}^{*}$ binds to the hep hollow site with the $\mathrm{OH}$ group pointing away from the surface $(\mathrm{BE}=-2.68 \mathrm{eV}) . \mathrm{BHOH}^{*}$ binds to the surface with the $\mathrm{B}$ atom over the $\mathrm{Au}$ atop site $(\mathrm{BE}=-2.36 \mathrm{eV})$. The hydrogen atom in the $\mathrm{B}-\mathrm{H}$ moiety points away from the surface and the $\mathrm{H}$ atom of the $\mathrm{O}-\mathrm{H}$ bond points toward the surface. Similar to $\mathrm{BH}_{2} \mathrm{OH}^{*}$, BHO* $^{*}$ has a relatively weak adsorption to the surface $(\mathrm{BE}=-0.22 \mathrm{eV})$. The $\mathrm{O}$ atom interacts with the $\mathrm{Cu}$ atop site and the $\mathrm{B}$ atom is over the $\mathrm{Au}$ atop site. Similar to $\mathrm{BOH}^{*}$, $\mathrm{BO}^{*}$ binds to the surface with the $\mathrm{B}$ over the hcp hollow site and $\mathrm{O}$ pointing away from the surface $(\mathrm{BE}=-2.98)$.

$\mathrm{BH}_{x} \mathrm{O}_{2}$ species. $\mathrm{BH}(\mathrm{OH})_{2}{ }^{*}$ is a stable gas phase species and, similar to binding to the $\mathrm{Au}(111)$ surface, does not bind strongly to the $\mathrm{Au}_{2} \mathrm{Cu}(111)$ surface. $\mathrm{B}(\mathrm{OH})_{2}{ }^{*}$ binds strongly to the $\mathrm{Au}$ atop site with the $\mathrm{H}$ atoms pointing toward the nearby $\mathrm{Au}$ and $\mathrm{Cu}$ atop sites $(\mathrm{BE}=-2.21 \mathrm{eV}) . \mathrm{BHOOH}^{*}$ binds to the surface with the $\mathrm{O}$ atom on the $\mathrm{Cu}$ atop site, the $\mathrm{H}$ atom on the $\mathrm{Au}$ atop site and $\mathrm{OH}$ group points away from the surface( $\mathrm{BE}=-1.72$ eV). $\mathrm{BOOH}^{*}$ is a stable species that binds weakly to the $\mathrm{Au}_{2} \mathrm{Cu}(111)$ surface $(\mathrm{BE}=-0.24$ $\mathrm{eV}) . \mathrm{BO}_{2}{ }^{*}$ binds with one $\mathrm{O}$ atom on the $\mathrm{Cu}$ atop site, the other $\mathrm{O}$ atom on the $\mathrm{Au}$ atop 
site. The $\mathrm{B}$ atom resides over the bridge site $(\mathrm{BE}=-2.36 \mathrm{eV}) . \mathrm{BO}_{2} *$ binding to the $\mathrm{Au}_{2} \mathrm{Cu}$ (111) surface is $0.41 \mathrm{eV}$ stronger than to the $\mathrm{Au}(111)$ surface.

\subsubsection{Elementary oxidation energetics of $\mathrm{BH}_{4}{ }^{*}$ oxidation over the $\mathrm{Au}_{2} \mathrm{Cu}(111)$ surface}

The DFT energies of surface bound intermediates can be used to construct a reaction free energy diagram. For a general oxidation reaction converting adsorbed reactant $\mathrm{R}^{*}$ to adsorbed oxidized product $\mathrm{O}^{*}$, the reaction and reaction free energy are written as:

$$
\begin{aligned}
& R^{*}+x \mathrm{OH}_{a q}^{-} \rightarrow \mathrm{O}^{*}+y \mathrm{H}_{2} \mathrm{O}_{a q}+n e^{-} \\
& \Delta G_{r x n}=G_{O^{*}}-n e U+y G_{H_{2} O_{a q}}-G_{R^{*}}-x G_{O H_{a q}^{-}}
\end{aligned}
$$

Equations 3 and 4 may represent either an elementary step or a collection of elementary steps, and combined with equation 2 can be used to construct a reaction energy free energy diagram with all states referenced to the initial aqueous borohydride ion. This approach was previously applied to construct reaction free energy diagrams for borohydride oxidation over the $\mathrm{Au}(111)$ and $\operatorname{Pt}(111)$ surfaces ${ }^{10-11}$.

The reaction energy diagram for borohydride oxidation over $\mathrm{Au}_{2} \mathrm{Cu}(111)$ is illustrated in Figure 3 at an electrode potential of $-0.45 \mathrm{~V}$. The initial adsorption free energy of the $\mathrm{BH}_{4}{ }^{-}$ion at $-0.45 \mathrm{~V}$ over the $\mathrm{Au}_{2} \mathrm{Cu}_{1}(111)$ surface is equivalent to the value

for the $\mathrm{Au}(111)$ surface at $-0.23 \mathrm{~V} \cdot{ }^{10}$ All the following oxidation reaction energies are exergonic and, therefore, favorable at this potential. Considering only the species along the minimum energy oxidation path, on average each species is $0.13 \mathrm{eV}$ more stable on the $\mathrm{Au}_{2} \mathrm{Cu}(111)$ surface than on the $\mathrm{Au}(111)$ surface. 


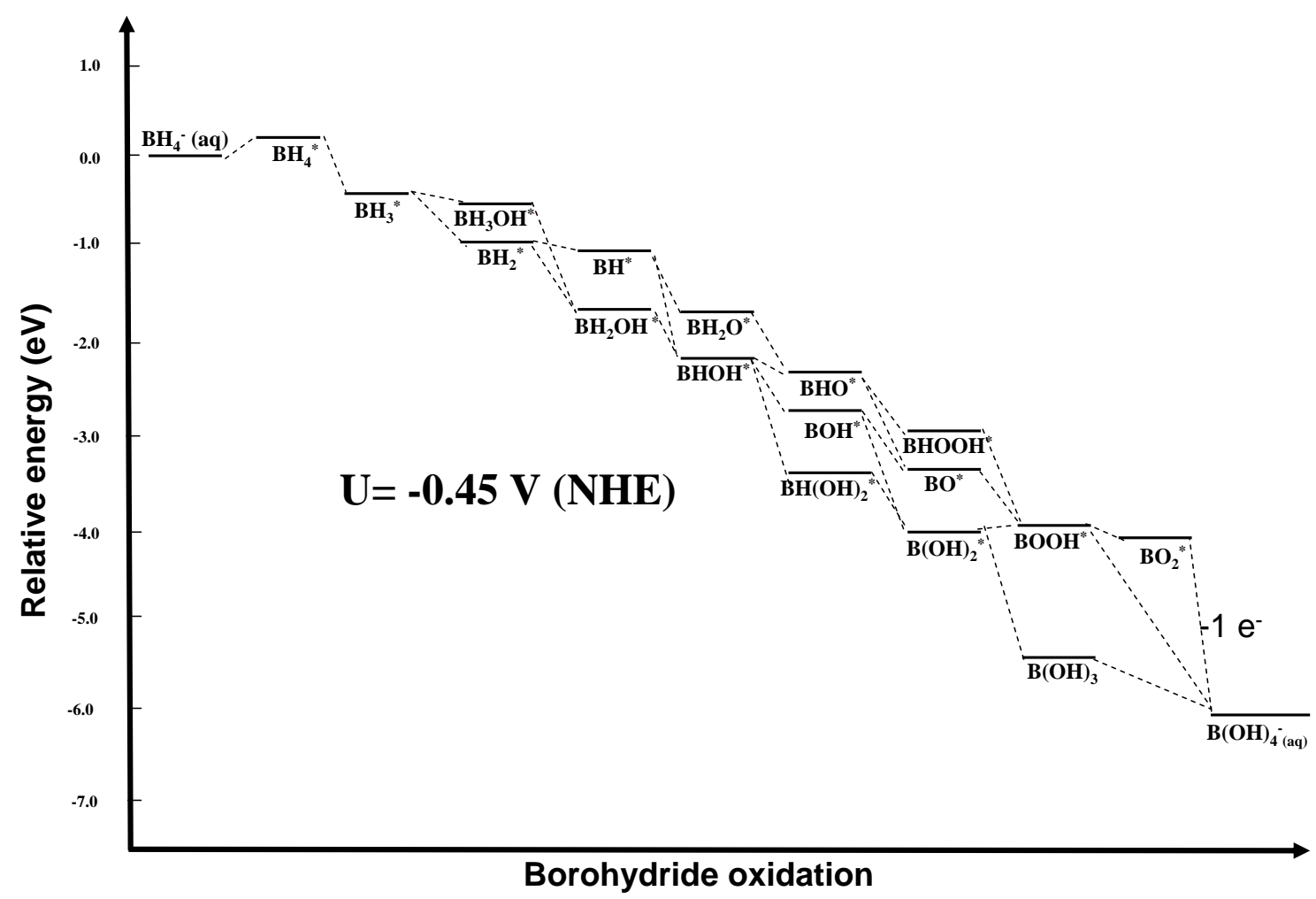

Figure 3. Reaction energy diagram for borohydride oxidation over the $\operatorname{Au}_{2} \mathrm{Cu}_{1}(111)$ surface at $-0.45 \mathrm{~V}$. Each step to the right indicates a $1 \mathrm{e}^{-}$oxidation step with the exception of the final product desorption step. Hydroxide ion reactants and water molecule products are left off the diagram for clarity. Dashed lines represent plausible elementary reactions. Conditions for free energy calculations: $\left[\mathrm{BH}_{4}{ }^{-}\right]=0.03 \mathrm{M},\left[\mathrm{OH}^{-}\right]=2 \mathrm{M}, \mathrm{T}=298 \mathrm{~K}$

\subsection{Activation barriers for dehydrogenation of $\mathrm{BH}_{4}{ }^{*}$}

The activation barriers for elementary surface reactions are not included in Figure 3. The activation energy corresponding to the first step of the mechanism of borohydride oxidation, the dehydrogenation of $\mathrm{BH}_{4}{ }^{*}$ to $\mathrm{BH}_{3}{ }^{*}$ (reaction 5) over $\mathrm{Au}_{2} \mathrm{Cu}_{1}(111)$, is presented in this section:

$$
\mathrm{BH}_{4} * \rightarrow \mathrm{BH}_{3} *+\mathrm{H}^{*}
$$

Figure 4 illustrates the most favorable adsorption configuration of reactant (a), intermediate of reaction (b) and products (c). The activation barrier for the lowest energy path of this reaction is $0.49 \mathrm{eV}$, which is $0.12 \mathrm{eV}$ higher than that obtained on $\mathrm{Au}(111)$ 
[1]. The transition state was confirmed to have a single imaginary harmonic oscillator frequency of $-262.7 \mathrm{~cm}^{-1}$.
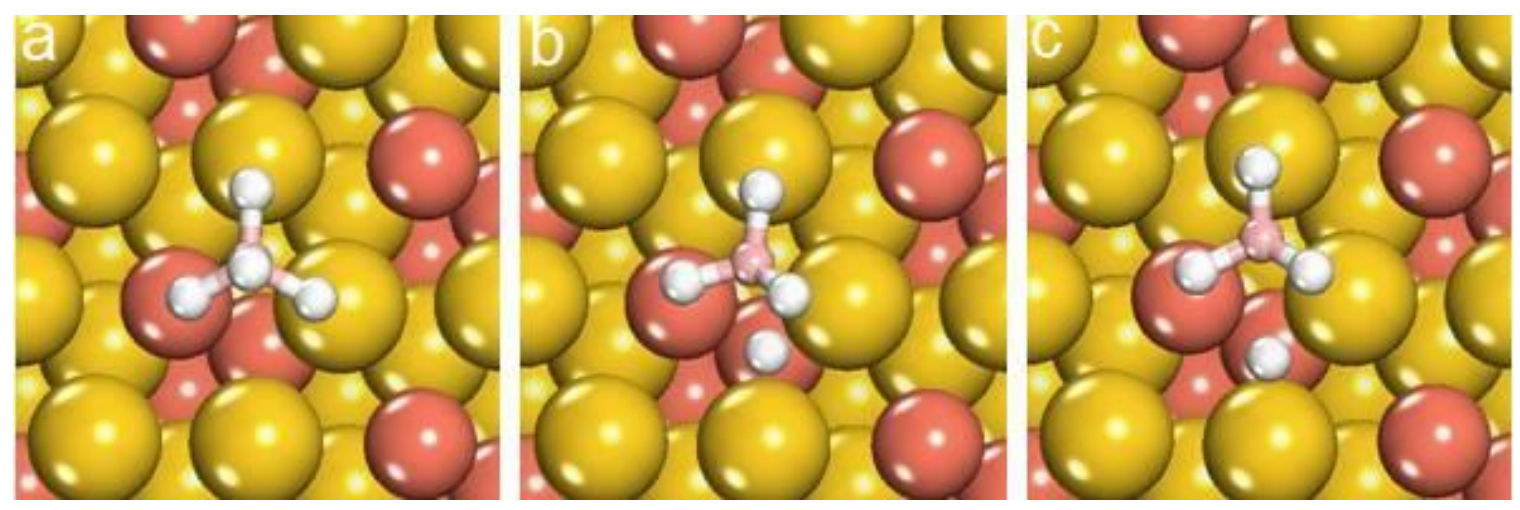

Figure 4. (a) Initial state, (b) transition state and (c) final state of the dehydrogenation of $\mathrm{BH}_{4}{ }^{*}$ to $\mathrm{BH}_{3}{ }^{*}$ over $\mathrm{Au}_{2} \mathrm{Cu}_{1}$ (111) surface.

A higher barrier of the first reaction step on $\mathrm{Au}_{2} \mathrm{Cu}(111)$ is a result of more stable initial state and shorter reaction coordinate for this reaction compared to the $\mathrm{Au}(111)$ surface. Though the activation barrier referenced to the initial state is higher over the $\mathrm{Au}_{2} \mathrm{Cu}(111)$ surface than the $\mathrm{Au}(1111)$ surface, the barrier is lower by $0.10 \mathrm{eV}$ on the bimetallic compared to the pure $\mathrm{Au}$ surface when the transition state is referenced to the non-bound $\mathrm{BH}_{4}{ }^{-}$state. As the initial $\mathrm{BH}_{4}{ }^{-}$adsorption is uphill in free energy at potentials of interest, the barrier relative to the non-bound state is kinetically relevant (ie, $\mathrm{BH}_{4}$ * coverage is low), and the intermetallic surface will offer more rapid initial activation of borohyride than the pure $\mathrm{Au}(111)$ surface.

\subsection{Activation barriers for dehydrogenation of $\mathrm{BH}_{3}{ }^{*}$}


The adsorption energy corresponding to the second step of the mechanism of borohydride oxidation, the dehydrogenation of $\mathrm{BH}_{3}{ }^{*}$ to $\mathrm{BH}_{2}{ }^{*}$ (reaction 6) over $\mathrm{Au}_{2} \mathrm{Cu}_{1}(111)$, is discussed in this section:

$$
\mathrm{BH}_{3}^{*} \rightarrow \mathrm{BH}_{2} *+\mathrm{H}^{*}
$$

$\mathrm{BH}_{3}{ }^{*}$ has been identified as a stable reaction intermediate for the BOR reaction. ${ }^{11}$

Figure 5 illustrates the most favorable adsorption configuration of reactant (a), intermediate of reaction (b) and products (c). The activation barrier for this reaction was $0.42 \mathrm{eV}$, which is $0.39 \mathrm{eV}$ lower than that obtained on $\mathrm{Au}(111)$ [1]. The transition state was confirmed to have a single imaginary harmonic oscillator frequency of $-541 \mathrm{~cm}^{-1}$.
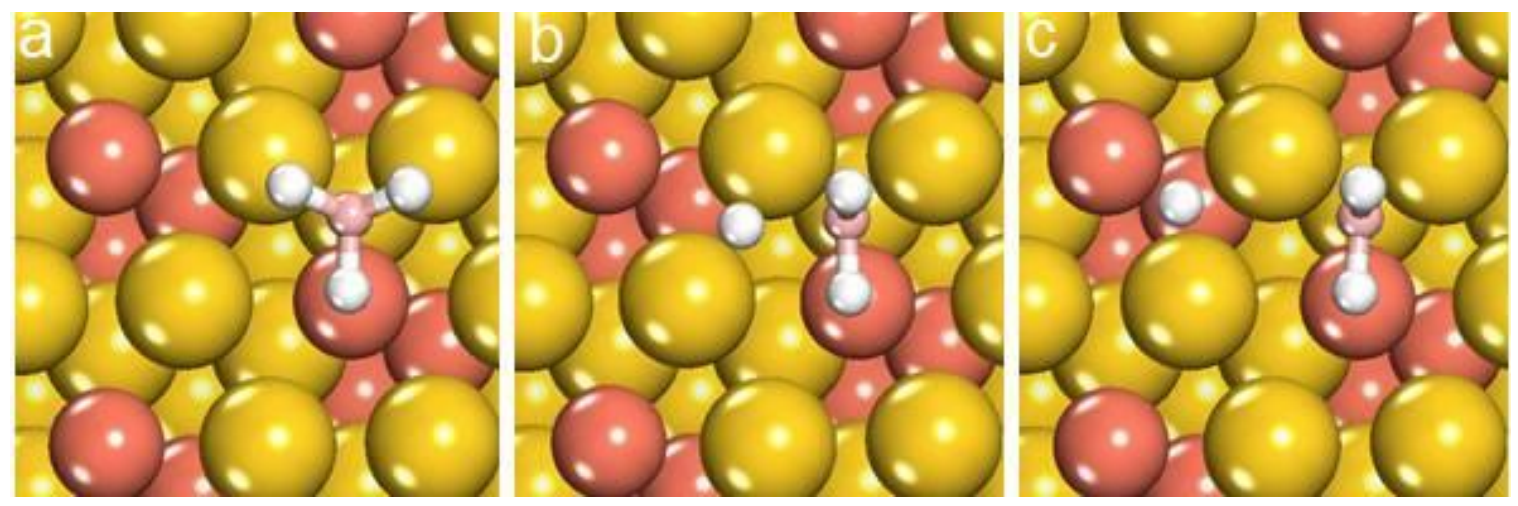

Figure 5. (a) Initial state, (b) transition state and (c) final state of the dehydrogenation of $\mathrm{BH}_{3}{ }^{*}$ to $\mathrm{BH}_{2}{ }^{*}$ over $\mathrm{Au}_{2} \mathrm{Cu}_{1}$ (111) surface.

\subsection{Activation barriers for dehydrogenation of $\mathrm{BH}_{2} \mathrm{OH}^{*}$}

$\mathrm{BH}_{2} \mathrm{OH}^{*}$ species are have been identified as the most stable reaction intermediate for borohydride oxidation over the $\mathrm{Au}(111)$ surface $^{11}$ The activation energy corresponding to $\mathrm{BH}_{2} \mathrm{OH}^{*}$ dehydrogenation (reaction 7) over $\mathrm{Au}_{2} \mathrm{Cu}_{1}(111$ ), is discussed in this section:

$$
\mathrm{BH}_{2} \mathrm{OH}^{*} \rightarrow \mathrm{BHOH}^{*}+\mathrm{H}^{*}
$$


Figure 6 illustrates the most favorable adsorption configuration of reactant (a), intermediate of reaction (b) and products (c). The activation barrier for this reaction was $0.39 \mathrm{eV}$, which is $0.67 \mathrm{eV}$ lower than that obtained on $\mathrm{Au}(111)$ [1]. The transition state was confirmed to have a single imaginary harmonic oscillator frequency of $-359 \mathrm{~cm}^{-1}$.
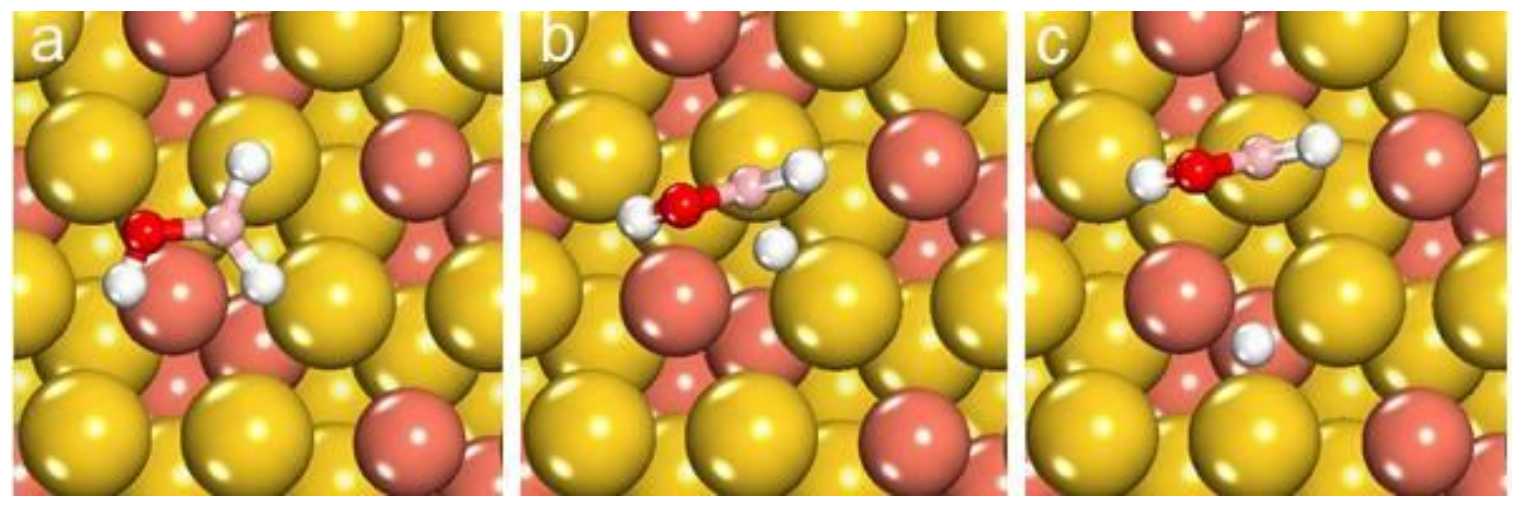

Figure 6. (a) Initial state, (b) transition state and (c) final state of the dehydrogenation of $\mathrm{BH}_{2} \mathrm{OH}^{*}$ to $\mathrm{BHOH}^{*}$ over $\mathrm{Au}_{2} \mathrm{Cu}_{1}$ (111) surface.

\subsection{Potential dependence of activation barriers}

The dehydrogenation barriers presented in the previous sections can be converted to potential dependent, electrochemical barriers using the method we have previously developed.$^{11,39}$ For example, the barrier for the electrochemical reaction,

$\mathrm{BH}_{4} *+\mathrm{OH}_{a q}^{-} \rightarrow \mathrm{BH}_{3} *+\mathrm{H}_{2} \mathrm{O}_{a q}+e^{-}$

is approximated using equation 9:

$E a(U)=E a^{0}-\beta\left(U-U_{0}\right)$

where $E a^{0}$ is the activation barrier of the chemical step, $\beta$ is the symmetry factor and $U_{0}$ is the equilibrium potential for surface hydrogen oxidation.

For the $\mathrm{Au}(111)$ surface, we previously determined $U_{0}$ and a $\beta$ value that allowed a DFT-based microkinetic model to match experimental kinetics, ${ }^{11}$ such that 
$E a(V)=E a^{0}-0.44(U+1.19)$

The calculated value for $U_{0}$ on $\mathrm{Au}_{2} \mathrm{Cu} 1(111)$ surface is $-1.03 \mathrm{~V}(\mathrm{NHE})$. Therefore, the activation barriers for electro-oxidation reactions over the Au2Cu1(111) surface is

$$
E a(V)=E a^{0}-0.44(U+1.03)
$$

where we presume an equivalent symmetry factor on the intermetallic surface. Initial electrocatalytic conversion of $\mathrm{BH}_{4} *$ (reaction 8) has a barrier, referenced to the solution phase $\mathrm{BH}_{4}{ }^{-}$ion, of $0.61 \mathrm{eV}$ over the $\mathrm{Au}(111)$ surface at $-0.5 \mathrm{~V}(\mathrm{NHE})$. The equivalent barrier on the $\mathrm{Au}_{2} \mathrm{Cu} 1(111)$ surface is $0.58 \mathrm{eV}$ at $-0.5 \mathrm{~V}(\mathrm{NHE})$, suggesting faster borohydride activation on the intermetallic. Similarly, the barrier for the electrochemical oxidation of $\mathrm{BH}_{3}$ on $\mathrm{Au}_{2} \mathrm{Cu}(111)$ at $-0.5 \mathrm{~V}(\mathrm{NHE})$ is $0.19 \mathrm{eV}, 0.32 \mathrm{eV}$ lower than on the $\mathrm{Au}(111)$ surface. For $\mathrm{BH}_{2} \mathrm{OH}$ oxidation, the $\mathrm{Au}_{2} \mathrm{Cu}(111)$ barrier of $0.16 \mathrm{eV}$ at -0.5 $\mathrm{V}(\mathrm{NHE})$ is $0.6 \mathrm{eV}$ less than the barrier on $\mathrm{Au}(111)$. The intermetallic is clearly significantly more active for the rate limiting B-H bond activation steps than the $\mathrm{Au}(111)$, suggesting it will produce more rapid borohydride oxidation kinetics.

\subsection{Experimental evaluation of $\mathrm{Au}-\mathrm{Cu}$ alloys for borohydride electrooxidation}

To realize the DFT predicted improved BOR performance of $\mathrm{AuCu}$ binary metal catalysts compared to a pure Au catalyst, we synthesized, characterized, and tested $\mathrm{AuCu}$ electrodes. Electrodeposition was used to prepare a $\mathrm{AuCu}$ film for electrokinetic testing. Prior to electrokinetic testing, X-ray diffraction (XRD) and energy dispersive $\mathrm{x}$-ray spectroscopy (EDS) were used to characterize the film.

\subsubsection{Deposited Au-Cu sample characterization with XRD and EDS}


Figure 7 shows the X-ray diffraction results for a $\mathrm{Au}-\mathrm{Cu}$ sample electrodeposited from a $1 \mathrm{mM} \mathrm{HAuCl}_{4}$ and $2 \mathrm{mM} \mathrm{CuSO}_{4}$ solution. Two peaks are identified in the $\mathrm{X}$-ray

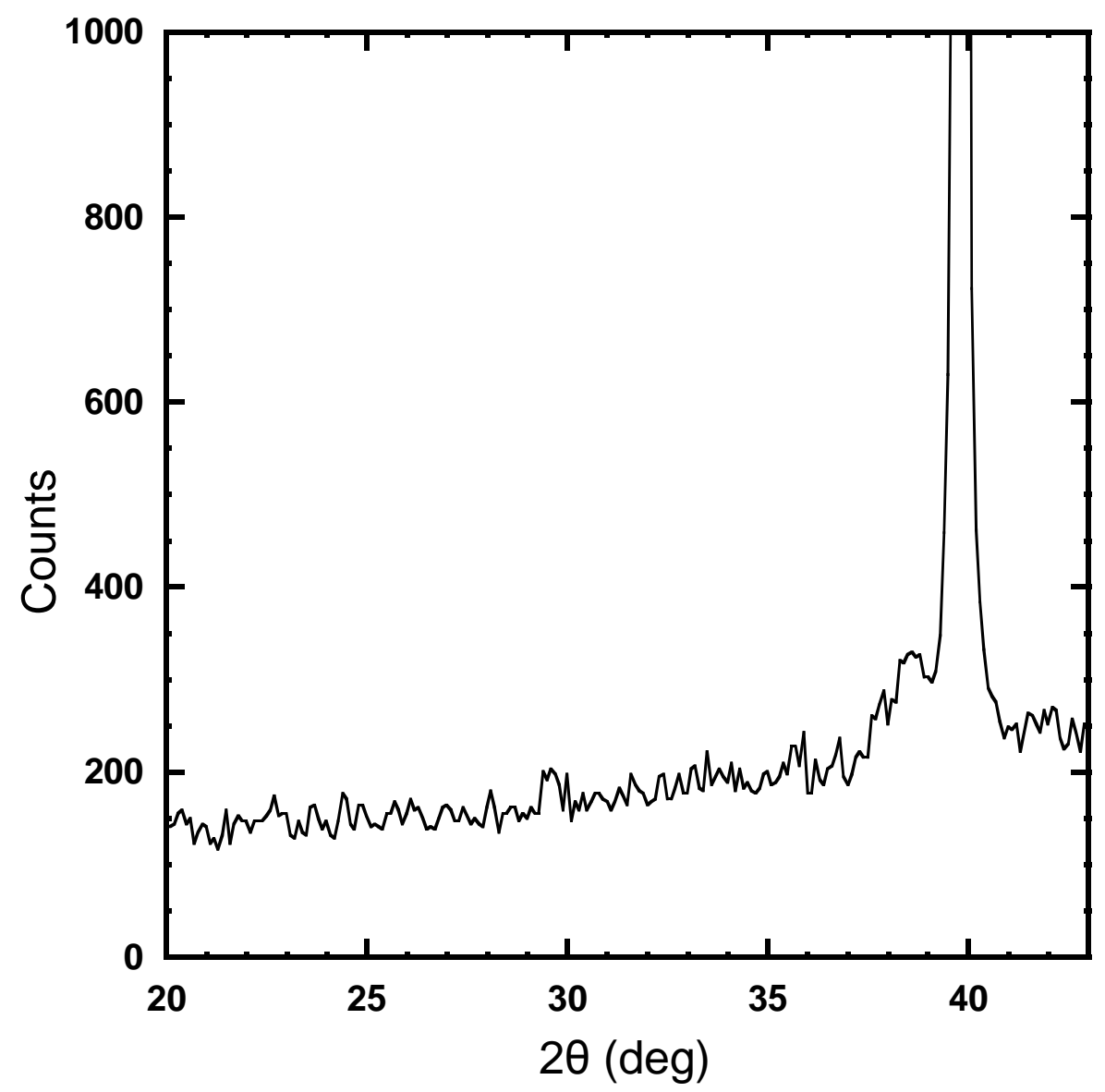

Figure 7. X-ray diffraction results for $\mathrm{Au}-\mathrm{Cu}$ sample deposited from a solution of $1 \mathrm{mM}$ $\mathrm{HAuCl}_{4}$ and $2 \mathrm{mM} \mathrm{CuSO}_{4}$.

pattern. The large peak indexes to the $\mathrm{Pt}(111)$ peak of the substrate electrode. A second peak identified at a $2 \theta$ of 38.592 corresponds to the electrodeposited $\mathrm{AuCu}(111)$ with a spacing of $d=2.33 \AA$ using Bragg's law. The assignment of this peak to the $\mathrm{AuCu}$ film was confirmed by varying the concentration of $\mathrm{Cu}$ precursor for electrodeposition such 
that a $100 \% \mathrm{Au}$ (Figure 8) and a $90 \% \mathrm{Cu}$ sample (not shown) were also prepared. The minor (111) peak was repeatable across multiple deposition experiments following the same protocol and does

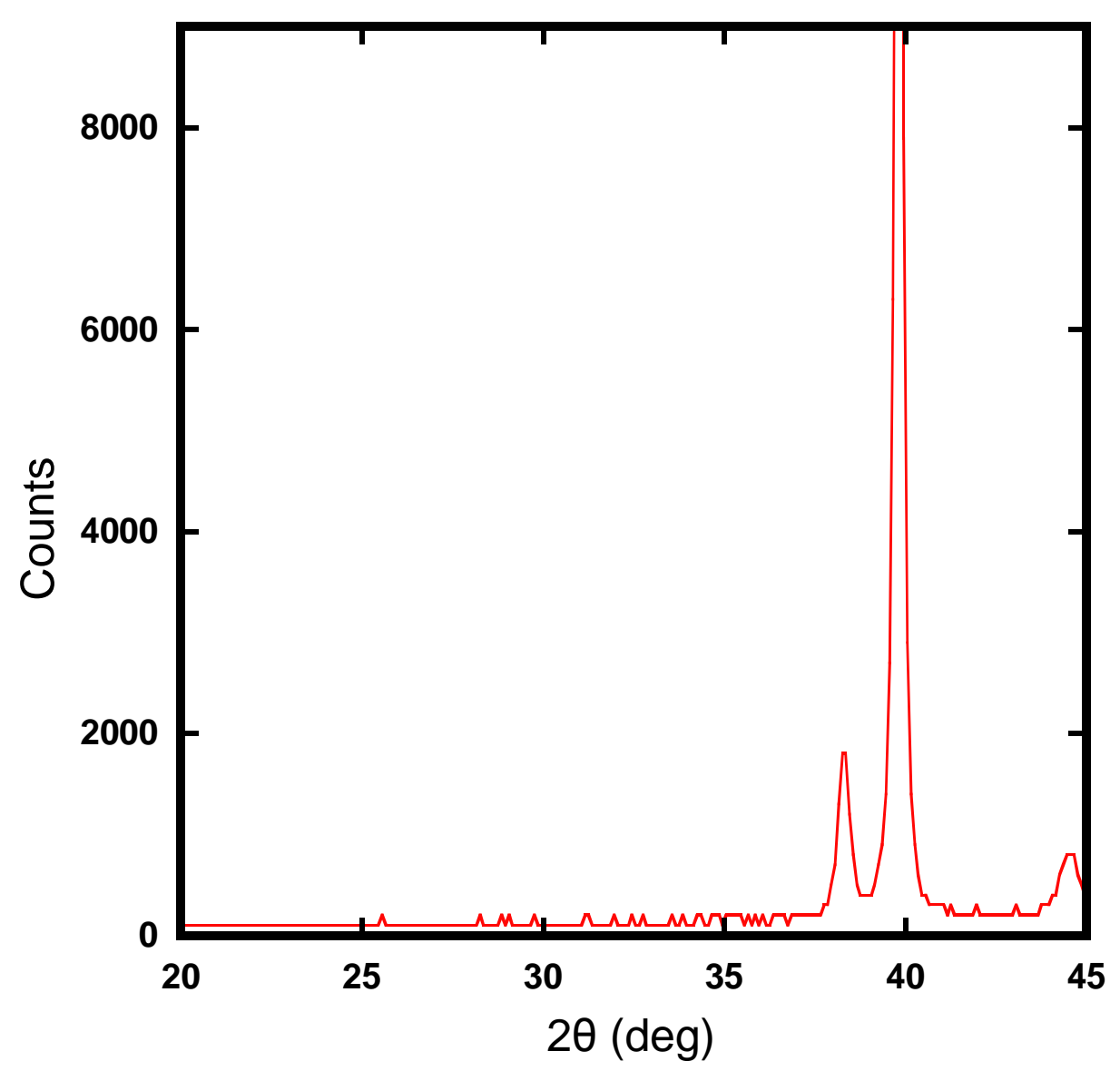

Figure 8. X-ray diffraction results for pure Au sample deposited from a solution of $3 \mathrm{mM}$ $\mathrm{HAuCl}_{4}$

not exist on the pure platinum diffraction pattern. This minor peak corresponds to a Au$\mathrm{Cu}$ (111) surface with a lattice constant of $4.036 \AA$. Based on the lattice constant the deposited film is $11.5 \% \mathrm{Cu}$ and $88.5 \% \mathrm{Au}$, as calibrated by a continuous curve derived from empirical potentials that fits well to experimentally measured lattice constants. ${ }^{32}$ 
A sample of $\mathrm{Au}-\mathrm{Cu}$ deposited alloy from a solution of $1 \mathrm{mM} \mathrm{HAuCl}_{4}$ and $5 \mathrm{mM}$ $\mathrm{CuSO}_{4}$ was confirmed by X-ray diffraction to have more than $60 \%$ copper which is not appropriate for DBFC application due to facile $\mathrm{Cu}$ oxidation. Though deposition of a $33 \% \mathrm{Cu}$ sample was desired, the composition of a sample deposited from a solution of $1 \mathrm{mM} \mathrm{HAuCl}_{4}$ and $3 \mathrm{mM} \mathrm{CuSO}_{4}$ was not possible to identify with XRD due to the integration of the $\mathrm{Au}-\mathrm{Cu}$ peak into the $\mathrm{Pt}(111)$ peak.

EDS was further used to confirm the presence and relative magnitudes of Au and $\mathrm{Cu}$ in the deposited films. Though quantitative analysis of the compositions was not attempted, EDS demonstrated that relative copper to gold peak areas increase with increasing copper precursor concentration in the deposition solution and is consistent with compositions determined by XRD experiments.

\subsubsection{Linear sweep voltammetry of borohydride oxidation of the Au-Cu binary metal}

Figure 9 shows the linear sweep voltammogram of pure copper deposited over the platinum substrate in a $2 \mathrm{M} \mathrm{NaOH}$ solution, without $\mathrm{NaBH}_{4}$ added. Only a small oxidation peak is observed at $-0.26 \mathrm{~V}(\mathrm{NHE})$, corresponding to the oxidation of the copper surface. Alternatively, the large oxidation peak at approximately $0 \mathrm{~V}$ likely corresponds

to the bulk oxidation and dissolution of the copper surface. ${ }^{40}$ Figure 10 presents the experimental linear sweep voltammetry results for the $\mathrm{Au}_{88.5} \mathrm{Cu}_{11.5}$ binary metal compared to a pure Au electrode. The borohydride oxidation peak for the Au electrode is at $-0.16 \mathrm{~V}$, whereas for the $\mathrm{Au}_{88.5} \mathrm{Cu}_{11.5}$ surface two oxidation peaks are observed. The first oxidation peak at $-0.33 \mathrm{~V}\left(\mathrm{NHE}\right.$ ) (Figure 10) for the $\mathrm{Au}_{88.5} \mathrm{Cu}_{11.5}$ electrode cannot be assigned to copper oxidation, and is instead assigned to the borohydride oxidation peak 
over the $\mathrm{Au}_{88.5} \mathrm{Cu}_{11.5}$ electrode. The second oxidation peak for the binary metal sample, at $-0.01 \mathrm{~V}(\mathrm{NHE})$, likely represents a mixed effect of borohydride oxidation and copper oxidation over the electrode surface. The $\mathrm{Au}_{88.5} \mathrm{Cu}_{11.5}$ electrode decreases the borohydride oxidation overpotential by $0.17 \mathrm{~V}$. The same value of $0.17 \mathrm{~V}$ is measured peak to peak and at a current of $2 \mathrm{~mA}$, suggested the difference does not arise from mass transfer differences between the two electrodes. The $0.17 \mathrm{~V}$ shift would correspond to a $10 \%$ increase in the overall

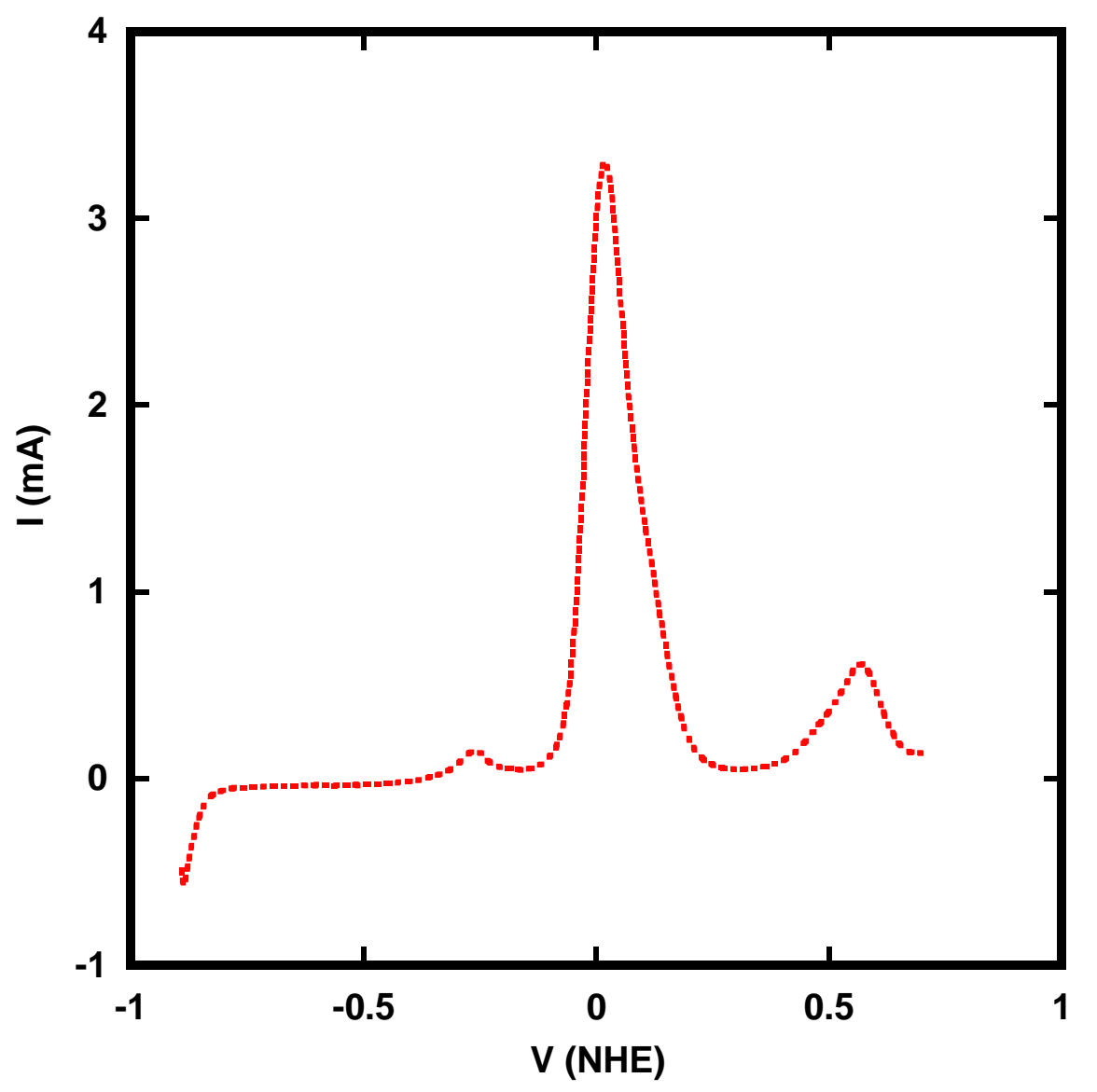

Figure 9. Linear sweep voltammogram of deposited pure copper in $2 \mathrm{M} \mathrm{NaOH}$ solution. Scan Rate $=25 \mathrm{mVs}^{-1}$, Electrode diameter $=5 \mathrm{~mm}, \mathrm{~T}=298 \mathrm{~K}$. 


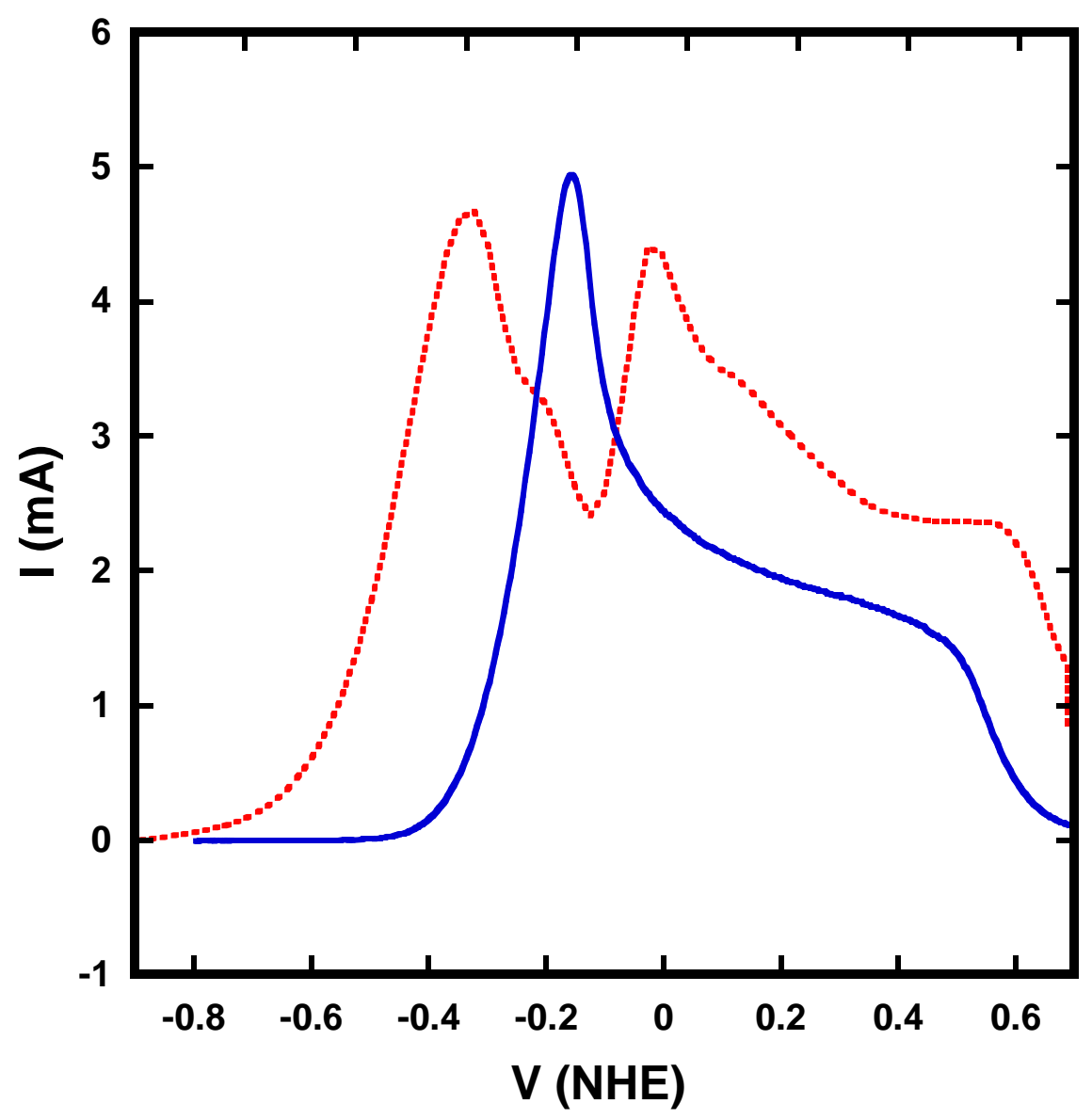

Figure 10. Borohydride oxidation over the $\mathrm{Au}_{88.5} \mathrm{Cu}_{11.5}$ surface (dashed red) compared to the pure gold electrode (solid blue). Electrode diameter in both cases $5 \mathrm{~mm}$, scan rate $=25$ $\mathrm{mVs}^{-1},\left[\mathrm{BH}_{4}^{-}\right]=0.03 \mathrm{M},\left[\mathrm{OH}^{-}\right]=2 \mathrm{M}, \mathrm{T}=298 \mathrm{~K}$

fuel cell efficiency, and is similar to the predicted shift based on DFT calculations for the $\mathrm{Au}_{2} \mathrm{Cu}_{1}(111)$ surface. However, the binary metal electrodes are not as oxidatively stable as a pure gold electrode, and their use would be limited to potentials lower than $-0.2 \mathrm{~V}$ to avoid catalyst oxidation in the high $\mathrm{pH}$ condition.

These results agree with that reported by $\mathrm{Yi}$ et al., ${ }^{41}$ who deposited $\mathrm{Au}-\mathrm{Cu}$ nanoparticles at different proportions $\left(\mathrm{Au} / \mathrm{C}, \mathrm{Au}_{75} \mathrm{Cu}_{25} / \mathrm{C}, \mathrm{Au}_{67} \mathrm{Cu}_{33} / \mathrm{C}, \mathrm{Au}_{50} \mathrm{Cu}_{50} / \mathrm{C}\right)$ on Carbon Vulcan and carried out cyclic voltammetry, chronopotentiometry and 
chronoamperometry for borohydride oxidation. The authors conclude that the optimum proportion of $\mathrm{Au}$ and $\mathrm{Cu}$ for borohydride oxidation was $\mathrm{Au}_{67} \mathrm{Cu}_{33}$, obtaining a current density $46 \%$ larger than using pure $\mathrm{Au} / \mathrm{C}$. An overpotential of $-0.70 \mathrm{~V}$ was measured when $\mathrm{Au}_{67} \mathrm{Cu}_{33} / \mathrm{C}$ was used compared to $-0.57 \mathrm{~V}$ on $\mathrm{Au} / \mathrm{C}$, improving the performance of the DBFC from $19.9 \mathrm{~mW} \mathrm{~cm}{ }^{-2}$ using $\mathrm{Au} / \mathrm{C}$ as the anode material to $51 \mathrm{~mW} \mathrm{~cm}^{-2}$ using $\mathrm{Au}_{67} \mathrm{Cu}_{33}$.

\subsection{Computational screening of borohydride adsorption over other surface alloys}

The AuCu binary metal BOR catalyst was arrived at based on a rationale of adding $\mathrm{Cu}$ to $\mathrm{Au}$ improve activity while providing more oxidative stability than pure $\mathrm{Cu}$. Similarly, we might expect binary compositions of group VIII and IB metals to balance the $\mathrm{BH}_{4}$ affinity and $\mathrm{B}-\mathrm{H}$ dissociation activity for a balance between activity and selectivity to direct oxidation. To explore the potential of other binary metal surfaces for improving the performance of BOR anodes, the borohydride ion adsorption free energy was evaluated. Strong dissociative adsorption is indicative of a very active catalyst, which is expected to produce to large amount of hydrogen and less than $8 \mathrm{e}^{-}$per $\mathrm{BH}_{4}{ }^{-}$ion converted. Metal/alloy surfaces with mild molecular adsorption at potentials between -0.5 to $-0.7 \mathrm{~V}$ could offer more activity while maintaining selectivity for the BOR. Table 3 presents the binding energy and adsorption free energy at $-0.5 \mathrm{~V}(\mathrm{NHE})$ of the $\mathrm{BH}_{4}{ }^{-}$ion over a series of VIII-IIB binary metal surfaces. Binary metals reported in Table 3 are surface alloys only and are not bulk intermetallic alloys. Using the $\mathrm{Ag}_{2} \mathrm{Ni}$ surface alloy as an example, a 4 layer slab is used in calculations. The first 3 layers are all $\mathrm{Ag}$ atoms, 
whereas the surface layer consists of $6 \mathrm{Ag}$ atoms and $3 \mathrm{Ni}$ atoms evenly distributed in the $3 \times 3$ cell.

Table 3. $\mathrm{BH}_{4}$ binding energies and $\mathrm{BH}_{4}{ }^{-}$ion adsorption free energies at $-0.5 \mathrm{~V}$ over Group VIII-IB binary metal (111) and (0001) surfaces (eV). The adsorption free energies to the pure $\mathrm{Au}$ and the $\mathrm{Au}_{2} \mathrm{Cu}_{1}$ intermetallic are reported for reference.

\begin{tabular}{|c|c|c|c|c|c|c|c|c|c|c|c|c|}
\hline $\begin{array}{c}\text { Surface } \\
\text { alloy }\end{array}$ & $\mathrm{Ag}_{2} \mathrm{Ni}$ & $\mathrm{Ag}_{2} \mathrm{Pd}$ & $\mathrm{Ag}_{2} \mathrm{Pt}$ & $\mathrm{Ag}_{2} \mathrm{Rh}$ & $\mathrm{Ag}_{2} \mathrm{Ru}$ & $\mathrm{Au}_{2} \mathrm{Ni}$ & $\mathrm{Au}_{2} \mathrm{Pd}$ & $\mathrm{Au}_{2} \mathrm{Pt}$ & $\mathrm{Au}_{2} \mathrm{Rh}$ & $\mathrm{Au}_{2} \mathrm{Ru}$ & $\mathrm{Au}$ & $\mathrm{Au}_{2} \mathrm{Cu}$ \\
\hline $\begin{array}{c}\text { Binding } \\
\text { energy (eV) }\end{array}$ & -2.88 & -2.55 & -2.58 & -2.64 & -2.7 & -2.66 & -2.13 & -2.22 & -2.34 & -2.35 & -1.73 & -2.08 \\
\hline $\begin{array}{c}\text { Adsorption } \\
\text { energy (eV) }\end{array}$ & -0.39 & -0.17 & -0.24 & -0.2 & -0.06 & 0.06 & 0.3 & 0.13 & 0.2 & 0.41 & 0.54 & 0.32 \\
\hline
\end{tabular}

Binding of borohydride species is stronger on all of these surfaces compared to the $\mathrm{Au}(111)$ surface, suggesting any of the surface alloys could be more active than a pure Au electrode. All of these surfaces allow for binding energies intermediate of the less active $\mathrm{Au}(111)$ surface and the non-selective $\operatorname{Pt}(111)$ surface, indicating a potential improvement in both activity and selectivity for the BOR in comparison with the pure metal surfaces. The adsorption to each of these surfaces may be classified as molecular, although the B-H bond over the Group VIII metal atom extends upon adsorption. For example, for the $\mathrm{Au}_{2} \mathrm{Pt}$ surface alloy, the lengths of $\mathrm{B}-\mathrm{H}$ bonds for the $\mathrm{H}$ atoms that interact with gold atop sites are $1.25 \AA$, whereas the bond length extends to $1.38 \AA$ for the $\mathrm{B}-\mathrm{H}$ bond with the $\mathrm{H}$ over the $\mathrm{Pt}$ atop site. This partial $\mathrm{B}-\mathrm{H}$ bond dissociation may indicate a tendency towards non-selective hydrolysis reactions, however, further mechanistic study would be needed and examination of the $\mathrm{H}$ recombination rate on the binary metal surface would merit consideration.

\section{Conclusions}


$\mathrm{AuCu}$ alloys are proposed as an alternative catalyst for borohydride direct oxidation based on DFT calculations and experimental linear sweep voltammetry results. Our DFT model predicts less endothermic adsorption of the $\mathrm{BH}_{4}{ }^{-}$ion, stronger binding of reaction intermediates to the $\mathrm{Au}_{2} \mathrm{Cu}_{1}(111)$ surface and, lower overall activation barrier in comparison to the $\mathrm{Au}(111)$ surface. This suggests that $\mathrm{AuCu}$ binary electrodes are more active than $\mathrm{Au}$ electrodes for borohydride anodic oxidation. Alternatively, due to the molecular adsorption of the $\mathrm{BH}_{4} *$ species over the catalyst binary metal surface, these electrodes could be as selective to complete oxidation as gold electrodes. $\mathrm{A} \mathrm{Au}-\mathrm{Cu}$ electrode was prepared using electrodeposition techniques and tested by linear sweep voltammetry experiments. At high concentrations of copper on the surface, surface oxidation prevents borohydride oxidation. At the composition of $11.5 \% \mathrm{Cu}, 88.5 \% \mathrm{Au}$, the BOR catalyst activity increased, indicated by a $0.17 \mathrm{~V}$ decrease in the anodic overpotential. This experimental result realized the predicted overpotential reduction from DFT calculation. This first-principles guided design demonstrates the use of theory to guide electrocatalyst design, beginning with mechanism determination and determination of key predictor energetics through rational evaluation of binary metal compositions and experimental realization of predicted improvements. A series of binary metal compositions were suggested that may offer improved BOR performance based on DFT results.

\section{Acknowledgements}

This work was supported by the National Science Foundation, Grant \# CBET - 1264104. 


\section{References}

1. Gyenge, E., Electrooxidation of borohydride on platinum and gold electrodes: implications for direct borohydride fuel cells. Electrochim. Acta 2004, 49, 965-978.

2. Mirkin, M. V.; Yang, H.; Bard, A. J., Borohydride Oxidation at a Gold Electrode. J. Electrochem. Soc. 1992, 139, 2212-2217.

3. Chatenet, M.; Micoud, F.; Roche, I.; Chainet, E., Kinetics of sodium borohydride direct oxidation and oxygen reduction in sodium hydroxide electrolyte - Part I. BH4electro-oxidation on Au and Ag catalysts. Electrochim. Acta 2006, 51 (25), 5459-5467. 4. Chatenet, M.; Lima, F. H. B.; Ticianelli, E. A., Gold is not a Faradaic-Efficient Borohydride Oxidation Electrocatalyst: An Online Electrochemical Mass Spectrometry Study. J. Electrochem. Soc. 2010, 157 (5), B697-B704.

5. $\quad$ Finkelstein, D. A.; Da Mota, N.; Cohen, J. L.; Abruna, H. D., Rotating Disk Electrode (RDE) Investigation of $\mathrm{BH} 4-$ and $\mathrm{BH} 3 \mathrm{OH}-$ Electro-oxidation at $\mathrm{Pt}$ and An: Implications for BH4- Fuel Cells. J. Phys. Chem. C 2009, 113 (45), 19700-19712. 6. Sanli, E.; Celikkan, H.; Uysal, B. Z.; Aksu, M. L., Anodic behavior of Ag metal electrode in direct borohydride fuel cells. International Journal of Hydrogen Energy 2006, 31, 1920-1924.

7. Liu, B. H.; Li, Z. P.; Suda, S., Electrocatalysts for the anodic oxidation of borohydrides. Electrochim. Acta 2004, 49, 3097-3105.

8. Cheng, H.; Scott, K.; Lovell, K., Material Aspects of the Design and Operation of Direct Borohydride Fuel Cells. Fuel Cells 2006, 5, 367-375.

9. Liu, B. H.; Li, Z. P.; Suda, S., Anodic Oxidation of Alkali Borohydrides Catalyzed by Nickel. J. Electrochem. Soc. 2003, 150, A398-A402.

10. Rostamikia, G.; Janik, M. J., Borohydride Oxidation over Au(111): A FirstPrinciples Mechanistic Study Relevant to Direct Borohydride Fuel Cells. J. Electrochem. Soc. 2009, 156, B86-B92.

11. Rostamikia, G.; Mendoza, A. J.; Hickner, M. A.; Janik, M. J., First-principles based microkinetic modeling of borohydride oxidation on a Au(111) electrode. J. Power Sources 2011, 196, 9228-9237.

12. Rostamikia, G.; Janik, M. J., First Principles Mechanistic Study of Borohydride Oxidation over the Pt(111) Surface. Electrochim. Acta 2010, 55, 1175-1183.

13. Merino-Jimenez, I.; Janik, M. J.; de Leon, C. P.; Walsh, F. C., Pd-Ir alloy as an anode material for borohydride oxidation. J. Power Sources 2014, 269, 498-508.

14. Atwan, M. H.; Macdonald, C. L. B.; Northwood, D. O.; Gyenge, E. L., Colloidal $\mathrm{Au}$ and Au-alloy catalysts for direct borohydride fuel cells: Electrocatalysis and fuel cell performance. J. Power Sources 2006, 158, 36-44.

15. Gyenge, E.; Atwan, M.; Northwood, D., Electrocatalysis of Borohydride Oxidation on Colloidal Pt and Pt-Alloys (Pt-Ir, Pt-Ni, and Pt-Au) and Application for Direct Borohydride Fuel Cell Anodes. J. Electrochem. Soc. 2006, 153, A150-A158. 16. Atwan, M. H.; Northwood, D. O.; Gyenge, E. L., Evaluation of colloidal Ag and Ag-alloys as anode electrocatalysts for direct borohyride fuel cells. International Journal of Hydrogen Energy 2007, 32, 3116-3125. 
17. Simoes, M.; Baranton, S.; Coutanceau, C., Electrooxidation of Sodium Borohydride at Pd, An, and PdxAu1-x Carbon-Supported Nanocatalysts. J. Phys. Chem. C 2009, 113 (30), 13369-13376.

18. He, P.; Wang, Y.; Wang, X.; Pei, F.; Wang, H.; Liu, L.; Yi, L., Investigation of carbon supported $\mathrm{Au}-\mathrm{Ni}$ bimetallic nanoparticles as electrocatalyst for direct borohydride fuel cell. J. Power Sources 2011, 196 (3), 1042-1047.

19. Šljukić, B.; Milikić, J.; Santos, D. M. F.; Sequeira, C. A. C.; Macciò, D.; Saccone, A., Electrocatalytic performance of Pt-Dy alloys for direct borohydride fuel cells. $J$. Power Sources 2014, 272, 335-343.

20. Olu, P.-Y.; Job, N.; Chatenet, M., Evaluation of anode (electro)catalytic materials for the direct borohydride fuel cell: Methods and benchmarks. J. Power Sources 2016, 327, 235-257.

21. Behmenyar, G.; Akın, A. N., Investigation of carbon supported $\mathrm{Pd}-\mathrm{Cu}$ nanoparticles as anode catalysts for direct borohydride fuel cell. J. Power Sources 2014, 249, 239-246.

22. Li, S.; Wang, L.; Chu, J.; Zhu, H.; Chen, Y.; Liu, Y., Investigation of Au@Co-B nanoparticles as anode catalyst for direct borohydride fuel cells. International Journal of Hydrogen Energy 2016, 41 (20), 8583-8588.

23. He, P.; Wang, X.; Liu, Y.; Liu, X.; Yi, L., Comparison of electrocatalytic activity of carbon-supported $\mathrm{Au}-\mathrm{M}(\mathrm{M}=\mathrm{Fe}, \mathrm{Co}, \mathrm{Ni}, \mathrm{Cu}$ and $\mathrm{Zn})$ bimetallic nanoparticles for direct borohydride fuel cells. International Journal of Hydrogen Energy 2012, 37 (16), 11984-11993.

24. Arevalo, R. L.; Escaño, M. C. S.; Kasai, H., Mechanistic Insight into the Au-3d Metal Alloy-Catalyzed Borohydride Electro-Oxidation: From Electronic Properties to Thermodynamics. ACS Catalysis 2013, 3 (12), 3031-3040.

25. Arevalo, R. L.; Escano, M. C. S.; Wang, A. Y.-S.; Kasai, H., Structure and stability of borohydride on $\mathrm{Au}(111)$ and $\mathrm{Au} 3 \mathrm{M}(111)(\mathrm{M}=\mathrm{Cr}, \mathrm{Mn}, \mathrm{Fe}, \mathrm{Co}, \mathrm{Ni})$ surfaces. Dalton Trans. 2013, 42 (3), 770-775.

26. Kresse, G.; Hafner, J., Ab initio molecular dynamics for liquid metals. Phys. Rev. B 1993, 47 (1), 558-561.

27. Kresse, G.; Furthmuller, J., Efficiency of ab-initio total energy calculations for metals and semiconductors using a plane-wave basis set. Computational Materials Science 1996, 6, 15-50.

28. Kresse, G.; Furthmuller, J., Efficient iterative schemes for ab initio total-energy calculations using a plane wave basis set. Phys. Rev. B 1996, 54 (16), 11169-11186.

29. Kresse, G.; Joubert, D., From ultrasoft pseudopotentials to the projector augmented-wave method. Phys. Rev. B 1999, 59 (3), 1758-1775.

30. Perdew, J. P.; Chevary, J. A.; Vosko, S. H.; Jackson, K. A.; Pederson, M. R.; Singh, D. J.; Fiolhais, C., Atoms, molecules, solids, and surfaces: Applications of the generalized gradient approximation for exchange and correlation. Phys. Rev. B 1992, 46 (11), 6671-7895.

31. Monkhorst, H. J.; Pack, J. D., SPECIAL POINTS FOR BRILLOUIN-ZONE INTEGRATIONS. Phys. Rev. B 1976, 13 (12), 5188-5192.

32. Ackland, G. J.; Vitek, V., MANY-BODY POTENTIALS AND ATOMICSCALE RELAXATIONS IN NOBLE-METAL ALLOYS. Phys. Rev. B 1990, 41 (15), 10324-10333. 
33. Rostamikia, G.; Janik, M. J., Direct borohydride oxidation: mechanism determination and design of alloy catalysts guided by density functional theory. Energy \& Environmental Science 2010, 3 (9), 1262-1274.

34. Duan, D. H.; Zhao, Y. F.; Liu, S. B.; Wu, A. L., Electrochemical Oxidation of Borohydride on Cu Electrode. Adv. Mater. Res. 2012, 347-353, 3264-3267.

35. Pourbaix, M., Atlas of Electrochemical Equilibria in Aqueous Solutions. NACE: Houston, TX, 1974.

36. Ateya, B. G.; Geh, G.; Carim, A. H.; Pickering, H. W., Selective Dissolution below the Critical Potential and Back Alloying in Copper-Gold Alloy. J. Electrochem. Soc. 2002, 149, B27-B33.

37. Duffo, G. S.; Farina, S. B.; Galvele, J. R., Stress corrosion cracking of 18 carat gold. Corros. Sci. 2004, 46, 1-4.

38. Fritz, J. D.; Pickering, H. W., Selective Anodic Dissolution of Cu-Au Alloys:

TEM and Current Transient Study. J. Electrochem. Soc. 1991, 138, 3209-3218.

39. Nie, X. W.; Esopi, M. R.; Janik, M. J.; Asthagiri, A., Selectivity of CO2

Reduction on Copper Electrodes: The Role of the Kinetics of Elementary Steps. Angewandte Chemie-International Edition 2013, 52 (9), 2459-2462.

40. Kang, M. C.; Gewirth, A. A., Voltammetric and force spectroscopic examination of oxide formation on $\mathrm{Cu}(111)$ in basic solution. J. Phys. Chem. B 2002, 106 (47), 1221112220.

41. Yi, L.; Song, Y.; Liu, X.; Wang, X.; Zou, G.; He, P.; Yi, W., High activity of Au$\mathrm{Cu} / \mathrm{C}$ electrocatalyst as anodic catalyst for direct borohydride-hydrogen peroxide fuel cell. International Journal of Hydrogen Energy 2011, 36 (24), 15775-15782. 